\title{
The 'Allegory on the Abdication of the Emperor Charles v' by Frans Francken II: Some Observations on the Iconography of Antwerp's Plight in the Early Seventeenth Century
}

\author{
Hendrik J. Horn
}

Volume 13, numéro 1, 1986

URI : https://id.erudit.org/iderudit/1073555ar

DOI : https://doi.org/10.7202/1073555ar

Aller au sommaire du numéro

\section{Éditeur(s)}

UAAC-AAUC (University Art Association of Canada | Association d'art des universités du Canada)

\section{ISSN}

0315-9906 (imprimé)

1918-4778 (numérique)

Découvrir la revue

\section{Citer cet article}

Horn, H. J. (1986). The 'Allegory on the Abdication of the Emperor Charles v' by Frans Francken II: Some Observations on the Iconography of Antwerp's Plight in the Early Seventeenth Century. RACAR : Revue d'art canadienne / Canadian Art Review, 13(1), 23-30. https://doi.org/10.7202/1073555ar

\section{Résumé de l'article}

Dans la partie de droite de L'abdication de Charles $V$ (vers 1630-1640), du peintre anversois Frans Francken II, une figure de Maure barbu symbolise le continent africain. Ce personnage ressemble étroitement au Roi de Tunis de Rubens, qui représente Mulay Ahmad, vassal tunisien de Charles v. L'apparition presque simultanée de Mulay Ahmad dans ces deux œuvres permet de penser qu'il personnifiait l'Afrique à l'époque où Charles $v$ régnait sur un immense empire catholique qui s'étendait aux quatre continents connus. Pour Francken II. Rubens et leurs contemporains anversois, le règne de Charles v devait apparaître comme une sorte d'âge d'or de l'histoire des Pays-Bas. La paix et la prospérité de cette période contrastait fortement avec les guerres sans fin et le déclin économique de leur propre époque. La fermeture du fleuve Escault à toute navigation (exception faite pour les bateaux hollandais) constituait une source majeure de mécontentement. Des œuvres comme La conquête de l'Afrique par Charles $V$ de Gaspar de Crayer. $L a$ bataille de Tunis de Rubens ou encore les créations de ce dernier pour l'entrée de l'Archiduc Ferdinand à Anvers, semblent bien opposer les gloires du temps de Charles $v$ aux malheurs de l'époque contemporaine. On peut dès lors conclure que l'abdication de Charles v, survenue trois quarts de siècle auparavant, continuait d'intéresser les contemporains de Francken II, car cet événement évoquait les personnages et les faits prestigieux d'un vaste empire dont faisaient partie les Pays-Bas, prospères et unifiés.
Tous droits réservés @ UAAC-AAUC (University Art Association of Canada | Association d'art des universités du Canada), 1986
Ce document est protégé par la loi sur le droit d'auteur. L'utilisation des services d'Érudit (y compris la reproduction) est assujettie à sa politique d'utilisation que vous pouvez consulter en ligne.

https://apropos.erudit.org/fr/usagers/politique-dutilisation/ 


\section{The 'Allegory on the Abdication of the Emperor Charles V'}

by Frans Francken II: Some Observations on the Iconography of Antwerp's Plight in the Early
Seventeenth Century

HENIRIK J. HORN

Lmiremsity of (inclph

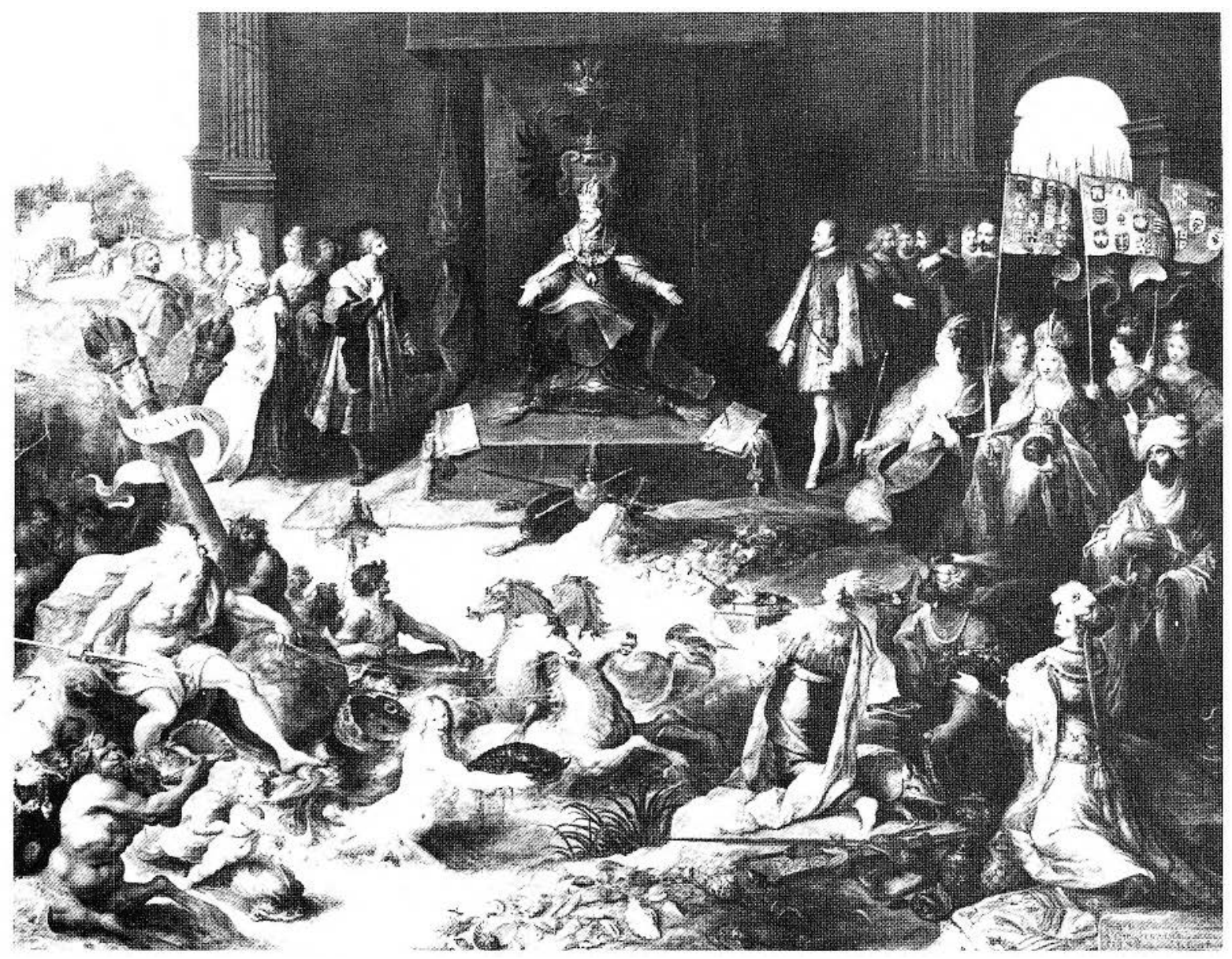

One of the most striking pantings in the Historical Section of the Rijksmuscum in Amsterclam is the Abdication of the Emperot Charles a (Fig. 1) be the Antwerp paimer frams francken the loumger $(1581-1642)$. This mallue work, dalling from circa $1630101640^{2}$ is known 10 historians of velherlandish art and culture not onle because of its risual appeal but also because of the opening remates be we late Hemi an de Waal in his magisterial I)uleh

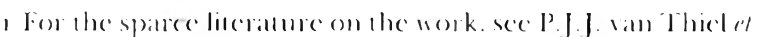

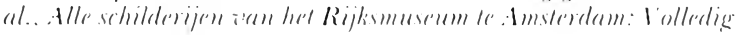

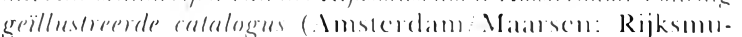

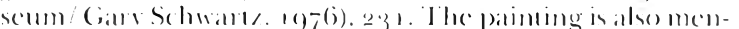

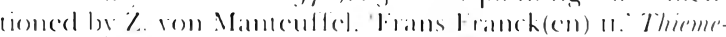

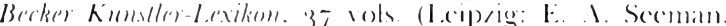

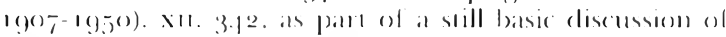

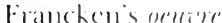

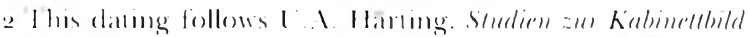

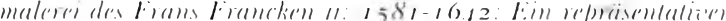

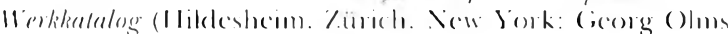

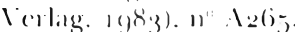


Portrayal of Histomy ( I 500-I 800): Anl Iconological Studs." Van de Waal uses the Abdication of Charles 1 as a characteristic example of the seventeenth century approach to history painting and compares it to a once celebrated painting of the same cvent by Louis Gallait (1810-1887), a work painted in 1842 (now in the Städelsches Kunstinstitut, Frankfort on the Main) that represents the Romantic approach to the historical subject (Iig. 2).' Van de Waal points out that Gallait craved the appearance of historical atuthenticity. The artist therefore seized on the poignant and historical anecdote of the ailing emperor,

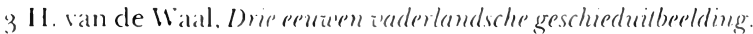
1500-1800: Finll iconologische s/udir. 2 vols. (The Hague: Martinus Nijhol, 1(9)2), 1, 1-2

1 l'an de Waal, $11,1,11$. 1/2. He wrongly datled the work 18,1 and apparently did not realize that is is a copr of a much larger version of 18.37101841 . now in the Musées des Bcaux-Arts de Belgigue in Brussels. ()ne wonders why Van de Waal did not comsult II . V'ollmer, 'I ouis Gallait.' ThremeBecker, xir, 101-102. For additional information on both the large and small versions of the work, see E. Holringer and H.J. Zicmke. I) ir (imalde des 19) Jehthunderts: Städelsches Kunsinstitul: Frankfurl am Main (Fankfort on the Main: Verlag G. Schulte-13ulmke, 1972), $118-120$

- Van de Waal, I, 1-2. Translation minc

6 Vor did Van de Watal attempt to explatin why Gallait chose the subject or, more precisels, why the Belgian Sialc commissioned lla large work now in Brussels. and King Willam in of the Vetherlands the smaller version now in Frankfort on the Main (Holzinger and \%icmke, $18-119$ )).

- lior much of the following exegesis, see the commentaly presented alongside the picture by the Rijksmuseum; J.P'. Vitu, Jan Comelis\% Vermeven, peintre de Tunis en 15.35." Bullelin des belles-lellres arabes, cxi. (1977), 246: H.J. I Iom. Charles r's Comquest of Tunis: Cartoons and Tapestries by Jan Comelisz l'emeyen (Yale Universits Dissertalion. 1977). 256: and Härting, $n^{\prime \prime} \mathrm{A2}_{2}\left(\mathrm{i}_{-}\right.$.

8 Soe Van de Waal, $1,1, n .2 / 1-2 / 4$. ()f (o)usc the main action is identified by the I all in inscription, but il contains so many abbreviations that it (an be of help only to an accomplished I atinist. This inscription reads: 'S. R. Imperiz spontanea resignatio a Carolo $\mathrm{V}$ Imp. an Ferd. I Fr. regnomumy. haered in Phlm. II Hisp. Regem Fil. Facta Brux. An 1555. Fix inien. D. Pelride" Ilamicarl." This means something like: "I he voluntarr abli(ation of the Iloly Roman Emperer (iharles $x$ in farom of Ferdinand 1 , his brother and heir to the kingdoms of Auswia and Hungary, and of Philip 1 , his son and king of Span. 1)onc in Brusscis in 155.5. As invented by don Petri di Hamnicart. Hammicart can have becm no major humanist, as

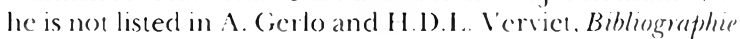
de l'humanisme des ancions. Pa!s-Bas: aiee un répertome bibliographique des humanisdes al poétes nér-latmis (Brussels: Presses (iniversitaires, 1()72)

9) Sec in this commection the description b. J.R. Martin, Th" Decorations for the I'ompa Introntus Firdinamdi (Iondon/ Vew York: Arcade Press. 1972), 105. of a part of one of ahe arches erected lor Archduke licrlinand's entry into Antwerp in 1535: "The god Neptunc is secn with the irident on the right side of (harles 1 ; the eprigraph on the pedestal

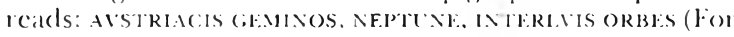
lhe Austrians. Neplune. rou wash lhe shores of bolle worlds). Charles r, whose empire extends beyond the dilanlic to the New World, mas rights be alled I ord of the Scat. who lcans on the shoulder of the young William of Orange. (iallait's unificd and plausible re-cnactment of the historical event could serve as a molel for the director ol a modern historical film, Van de Waal says, whereas Frans Francken il presents an improbable combination of festive allegories and frontally composed historical events. 'Even the unity of the time turns out to be wanting, 'he observes perceptively, 'for in the left background one sces how the emperor has himself conveyed in a litter borne by two mules to the monastery [of San Geronimo in Yuste] in which he will pass the last ycars of his life. "Van de Waal further notes Francken's apparent disclain for the kind of anecdotal detail so dear to the heart of the Romantic painter.

This is the limit of Van de Waal's interest in the painting at least within the compass of his study. His only concern is with the work as a generic cxample of the seventecnth-century approach to history painting. In that context he could have discussed the penchant of Baroque history painters for clevating hiscorical crents to a higher, ideal planc, but he apparently has no interest in Francken's work per se and does not stop to ask why this event of 1555 should have been celebrated in a painting of about the fourlh decade of the scventeenth century." It is this question that is the subject of the present essay. The answer necessarily takes us to works by Rubens and other contemporary lilemish artists and to the economic plight of Antwerp in the early seventeenth century.

Van de Waal alludes to 'the allegories of the continents, lands, and seas in the foreground' of Francken's Abdication of Charles 1.i The picture shows Charles $v$ dividing his dominions between Philip, his son on his left, and Ferdinand, his brother on his right. $\Lambda_{n}$ understanding of the historical event is necessary to identify them, ${ }^{*}$ for none of the principal actors is a good likencss, not even Charles himself. The emperor wears the Order of the Golden Fleece and sits on a throne garnished by the Austrian double-headed cagle. He is shown quite litcrally laving down his power, for his sword, sceptre, and imperial orb lic on a cushion at his feet. In the left foreground, Neptunc, in the company of Iritons, Nercides and the like, represents the seas of Charles' world empire." Behind Neptunc wc see one of the twin columns of Hercules with Charles' favourite motto. 'Plus Lltra,' meaning 'still lurther' or 'further beyond,' which symbolized the emperor's mission to carry the (hristian faith across the seas, beyond the boundarics of the columns planted by Horcules at Gibraltar." In the right foreground three women kneel who probably represent (from lefi to right) Europe, America and India. Not only their costumes identify the second and third, but also an abundance

\section{$\leftarrow$}

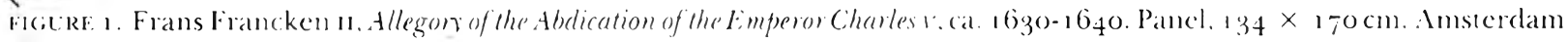
Rijksmuseum (Photo: Rijksmuseum) 


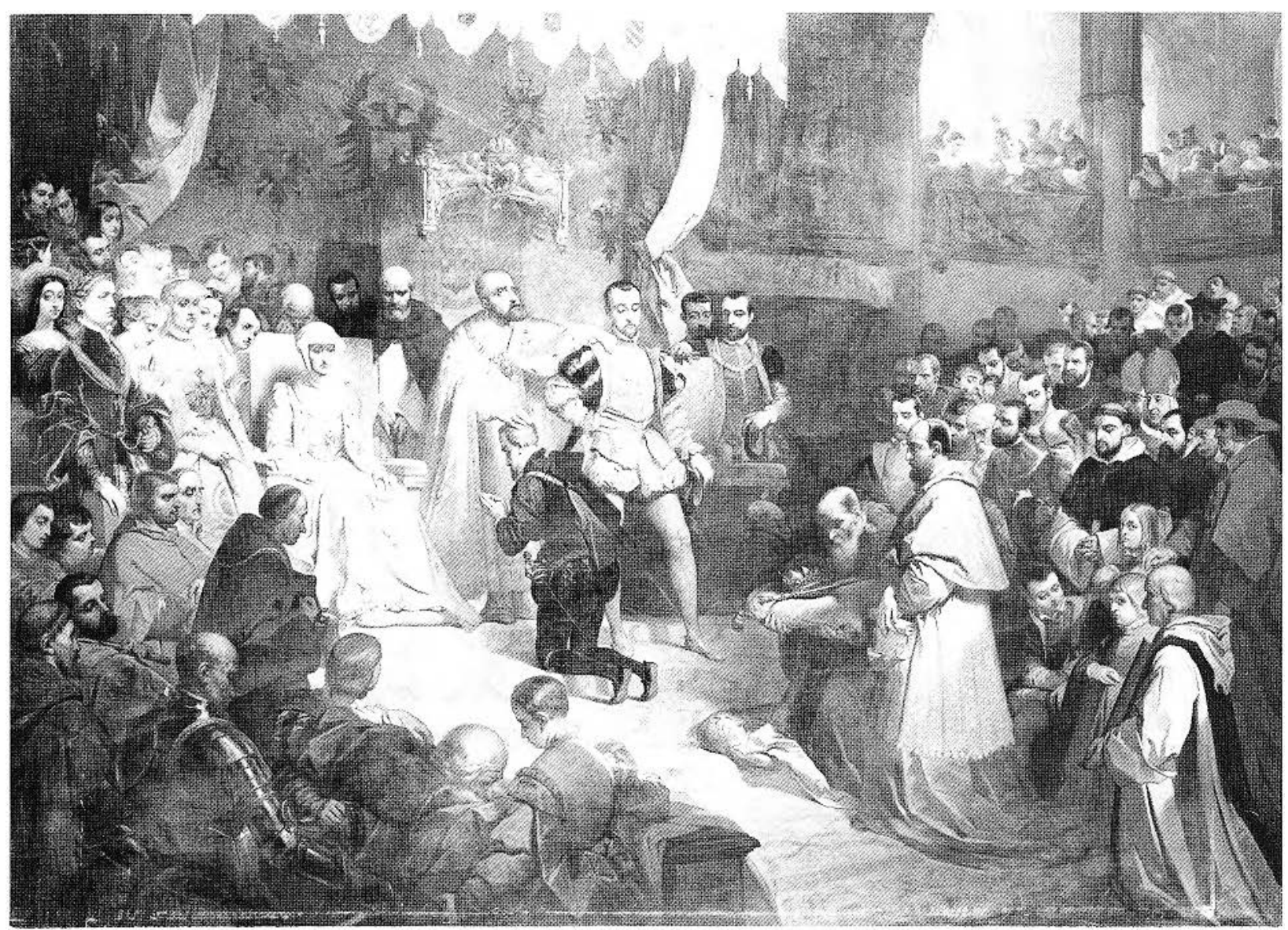

figure 2. Louis (iallait. The Abdication of the Emperor (iharles 1. $184_{2} 2$. Canvas, $121 \times 170 \mathrm{~cm}$. Frankfort on ihe Main, Städelsches Kunstinstitut (Photo: Städelsches).

of exotic objects and animals. The armadillo, for instance, is native only to South $\Lambda$ merica. The threc crowned women in the right background hold banners with the arms of the serenteen provinces of the northern and southern. Vetherlands, and of Charles' Spanish and Italian possessions.

This incentory leaves three allegorical figures moaccounted for. Immediately to Philip's right. a woman holding a sceptre probabls represents the Habsburg homeland of Austria. To her left. a ligure holding the imperial orb may well represent the I Ioly Roman Fmpire, whose leadership (Charles was surrendering 10 Ferdinand. At the right border, finalls. stands a VIoor who bears an ummistakable resemblance to the King of Timis, painted about 1620 by Francken's fellow townsman Peter Paul Rubcrus (Fig. 3). "Placed to the right of Europe, the Americas and India, he almost cortainly personilies Spain's African possessions or. 10 put it more accuratels. ('harles l's Mrican ambitions.

The name of Charles v became associated with the continent of Alrica by way of his conquest of Tumis in 1.535. The emperor defeated the Berber pirate and (Otoman admiral. Kheir-ed-Din Barbarossa. bun
10 Viu de Waal, 11, 1, 11. 1/4. For more complete and up-todate information about the origins and meaning of the device, see E. Rosenthal. 'Plus uluar. Xon plus ultuat. And the

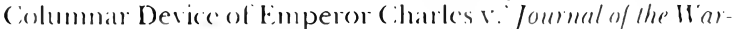

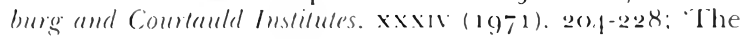
Invention of the (olumnar bevice of timperot (hatres rat the (ooure of Burgundy in Flanders in 1510 . ibid. xxxit (1073), 108-236, and Plus Ouldre, the Idea Imperial of (hatles $x$ in his (columnar Device in the Alhambral, in $\mathrm{R}$.

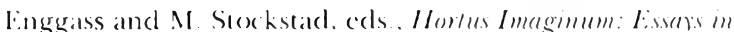

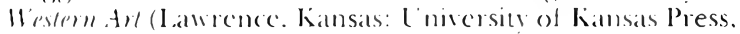
$10-19), 8,-(9) 3$

1 For the basic study of this painting, sec J S. Iledel. 'Rubens' King of Tums and Vermeven's Portrate of Mulat Ahmad, The Arl Quarterly. III (1940). 173-181. The date that I give follows Helal, i-9.

12 The (mp)eror was insoled in orher African rontures. the sicege of Cherchell in 1530 and the expedition anganst Algices of 1541 , but he was not present al the former and had (1) abandon the latter due (o) a terrible storm. Sor R.B. Nerriman. The Rise of the Spemish limpire in the Old Wontel and

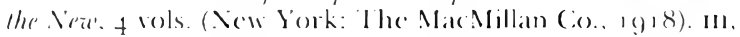

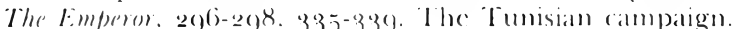
however. was a successful and colebrated crusade. ('ven if. esperially from a mextern point of view, it had its shate of flaws and ironies. Sec A. I. Anderews. The Compresign of the Limperon Charles a agames Tumis and Kheir-ed-Din Barbarossa

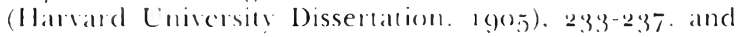
Ilom. 11-12. 


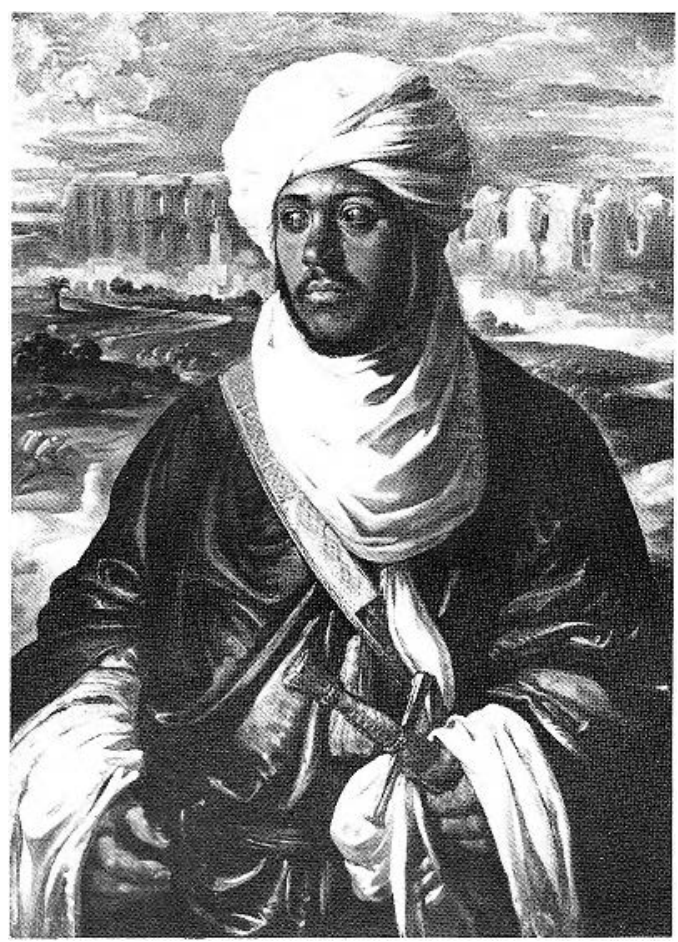

Figure 3. Peter Paul Rubens. The King of Tunis, ca. 1620 . Canvas, $100.3 \times 71.1 \mathrm{~cm}$. Boston. Museum of Fine Arts (Photo: Muscum of Finc Arts).

allowed him to escapc. (harles then restored to his throne Mulav I Iasan. a notoriously crucl and corrupt ruler as well as an Infidel. Furthemore. Hasan's period of rencwed tenure as rassal of Chates 1 was shortlived, for in $154^{2}$ his equally cruel son Mulay Ahmad blinded and deposed him. ${ }^{13}$

Rubens' King of 'Tumis is in fact Mulay Ahmad. 'The portrait is probably based on a painting or drawing of Mulay Ahmad by the war-artist of the Tumis expedi-

13 Held. 179

14 Hold. $177-1-8$. who considered onl the possibilits of a los painting by vermeren

15 Sec A. F. Popham. (atalogue of Eechings br Jan Cornclis\%.

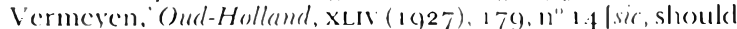
be $n^{\circ}, 3 \mid$. In addition to the impressions listed be Popham there is one in the Rijksprentenkabinet in Amsterdam and another in the Museum Bormans van Beuningen in Rotterdam (which I illustrate). The lulat thmad was mo (loublone of several of Vermerens depictions of the expedition that were protected be his imperial monopols of 15.56 and $1.53^{6}$. Sec Horn. $25-27$

16 Iteld. 179-180), and WI. (;. Constable. Rubens in the Mascum of Finc Arts Boston, in (;. Theomis, ed., Miscellaned

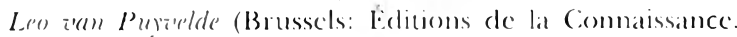
1(1)49), 12(9-130. Alumad also appears in Rubens Lion I/unl in the Musece des Batux-Arts in Rennes.

17 this proposition goes well berond the assertion of Ileld. 179), that io Rubens the King of I Iunis was probably just the hero of a romantic tradition. one of the African natives who had made common cause with the most atholic emperor (Charles 1 in his struggle against the Turks.

$18 \%$ \% mans Duth and Belgian readers the following material is common knowledge. For detailed and reliable informattion in linglish, sec S. I. Bindeff. The Schelde Question 10 1839 (I.ondon: Allen and L'nwin. 1945). $82-107$.

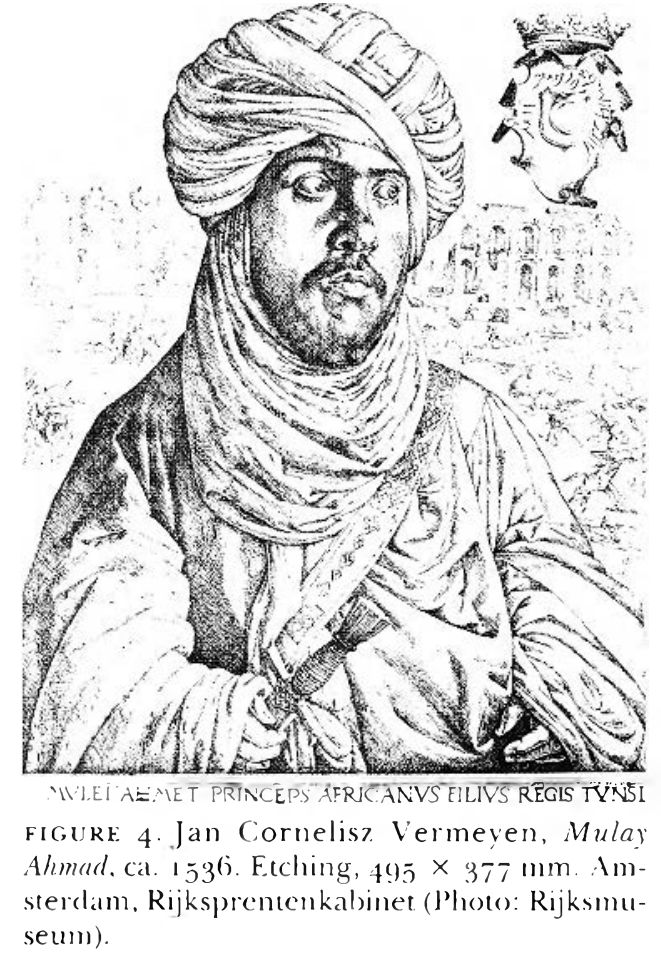

tion, Jan Comelis\% Vermeyen (1500-1559)), ${ }^{14}$ a lost work that also stood as model for Vermeren's own etched portrait of $\Lambda$ hmad (Fig. 4). ${ }^{\text {is }}$ It is unlikely that Rubens was concerned about historical details when he painted his King of Tunis and used the features of Mulat Ahmad for the Moorish kings in several of his depictions of the Adoration of the Magi." But that the portrait of Mulas Ahmad meant more to Rubens and contemporary lilemish artists than simply a portrait of a Moor is suggested by the near-simultancous appearance of Ahmad in Frans Francken n's Abdication of Charles r. Francken's painting allow's the hypothesis that the ligure of Mulay Ahmad personified Africa at a time when Charles v ruled over an cnormous Catholic empire that extended to all lour of the known continents."

A digression into screntcenth-century political and diplomatic history is necessary. ${ }^{10}$ The period uncler discussion, the ifigos, falls well past the midway point of the fighty Years War, which ran firom shortly after the arrival of the Duke of Allat in the Netherlands in $15^{6} 7$ to the complete recognition of the legitimacy and independence of the Dutch Republic in 1648 . The hostilities soon dismupted the track of Antwerp, the only decp-sca port of the southern Vetherlands. By $158_{5}$. the year in which rebellious Antwerp fell to the Spaniards under the command of the Duke of Parma. the Dutch conwrolled the Schelde estuary and had cut the port of 
from the North Sea. Spain and the Spanish Netherlands signed a truce with the Dutch Republic in 1609 , but the Scheldt remained closed to all but Dutch shipping. With the benefit of hindsight it seems that Spain's hopes of recovering the rebellious northem provinces had evaporated by that year. But, after the tcrmination of the (ruce in 1621 , Spain continued to wage war and intrigue against the Dutch.

The reunification of the Netherlands under the rule of the Spanish crown and the Catholic faith was one of the constant objectives of Rubens' efforts as a diplomat. ${ }^{19}$ Rubens himself apparently believed deeply in this cause and expressed his convictions in his art. $\Lambda s$.Müller-Hofstede has argued convincingly, Rubens repeatedly copicd Titian's portraits of Charles $v$ because, to Rubens, (harles personified the first hall of the sixteenth century, when the Netherlands were still unified under the rule of onc Catholic and Spanish king. ${ }^{20}$

I his ideal also show's up in two paintings by the Ghent painter Gaspar de Crayer $\left(1584^{-1} 669\right) .{ }^{.11}$ The works in question were displayed on one of two triumphal arches erected on the occasion of the entry of Archduke Ferdinand into Ghent in 163.5. In this case the allegorical method is once again in full flower. The capture of $A$ frica by Charles $v$ (who was born in (Ghent) is held up as an example for Ferdinand (Fig. 5). Hans Vlieghe writes:

Drcssed in armour and decked with the atuributes of his imperial dignity, Charles v steps out of a sloop and grabs a frightened woman br the arm. Her skin is brown and she wears an clephant's trunk with two tusks over her long hair. She is A frica and can also be recognized by the animals that accompany her and that, according to the Icomologia of Cesare Ripa, are her attributes: the lion, the scorpion, the snakes..."

In addition, the connection between (harles $v$ and his great progenit or Scipio $\Lambda$ fricanus is spelled out by mcans of a depiction of the (riumph of Scipio. I)oubtless the hope cxpressed by these paintings was that Ferdinand would smile on (ihent and re-establish the unity and prosperity of the mid-sixtecuth century, thus earning him a place in the ranks of such herocs as Charles and Scipio. ${ }^{23}$

19) Ihis statement. Which again borders on (ommon knowledge, could only be fully documented by an armslength bibliography. For a single source, sec R.S. Mac: Furn. The Letlers of P'eler Paul Rubens (Cambridge, Mass.: I Iarvard University Press, 1955), 14-16,161-167,221-227,28(3-20), $3.57-363.3$

20) J. Müllcr-Holstede, Rubens und T ivian: dats Bild Karls I. Münchner Jahrbuch de' bildende'n Kunst, xvili (1967). 81

2 I Sce C: Van de Velde and H. V'lieghe. Stadi'nsiermgen le' G'nl voor de Blijde Introde aren de Kardinaal-Infam/ (C)udheidliundig Museum, Abdij van Bijloke. (ihent, Ig(jg). 39-40). $57-59 \cdot() 1.99$, and figs. 44. 15. 50 .

22 Van de Velele and Vlicghe, 5 . Tianslation mine. I quose only a fraction of their fascinating material on this work.

23 For the similar sentiments addressed by Jacob Foldheer of Antwerp to the Archoluke ficrdinand at the time of the latter's cntry into that city in 1635 , see Martin, 215-216: And he concluded in unavendably threadlare phrases. w declaring that public praycis had been oflered "for the health and safoly of Your Serene llighness, so that this cils.

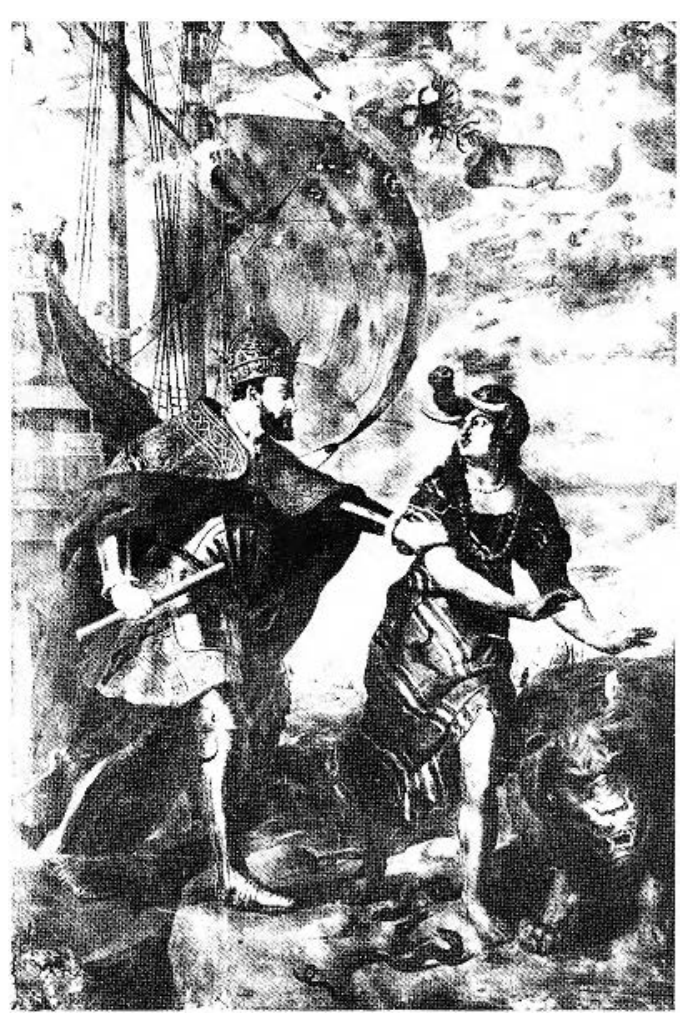

FIGURE j. Gaspar de Crayer, Charles I Conquers Africa. 1635 . Pancl, $459 \times 30^{\circ} \mathrm{cm}$. (Bhcmt. Museum van Bijloke (Photo: Clacrhout)

It is with the notion of Charles $v$ as the paragon of Habshurg virtuc that we arrive at the key to the meaning of the most well-known treatmont for the serentcenth century (or ans other) of (harles r.s African ambitions, ${ }^{21}$ Rubens' Balle of Tumis (Fig. (i). ${ }^{2.5}$ In this painting, which is generally dated around 1620 but sometimes as late as $1638 .{ }^{8}$ Rubens may have meant to depict the battle of the wells. in which Charles 1 led his intermational forces to the important victory that preceded the Lall of lunis." Rubens depicted the battle as a mêléc of Christians and infidels, with little respect for fact in either the disposi-

which owes its extratordinary growh to lhe divine (emperors Maximilian I and (hanles 1 , and other ancestors of yours, will surely recorer. logether with all the Belgian provinces. its former splendom and peace under your gorermmont and protection"

24 Several lessor known evonatoms of the oront will be discussed in me forthcoming monogriph on V comcren and his Compunst of Timis scries.

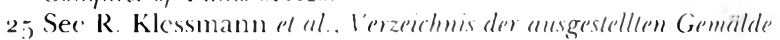
de's 1 3. bis 18 . Jahrhunderts im . Museum I)ahlem (Berlin: Brïder

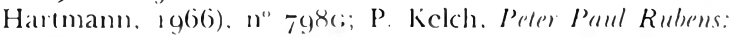

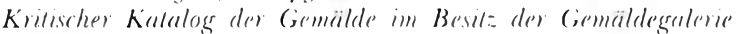
Berlin (Bcrlin-Dahlem: Reiler 1)ruck. 19-8), 7:3-78: and J.S.

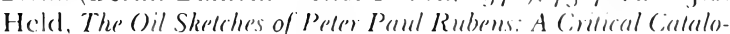
gue, 2 vols. (Princeton. Xew Jerser: Princeton I niversits Press, $198(0)$. 1. $38(i-388$.

26 Sce Held, ()il Skelches, 1.387

27 Andrews. 20.2-207. Held. ()il Sketches. 1386 . proposes that the painting depicis the batulc of Jume lo. Docs he mean the battle for (ioleta, which took place on July 1 () : 


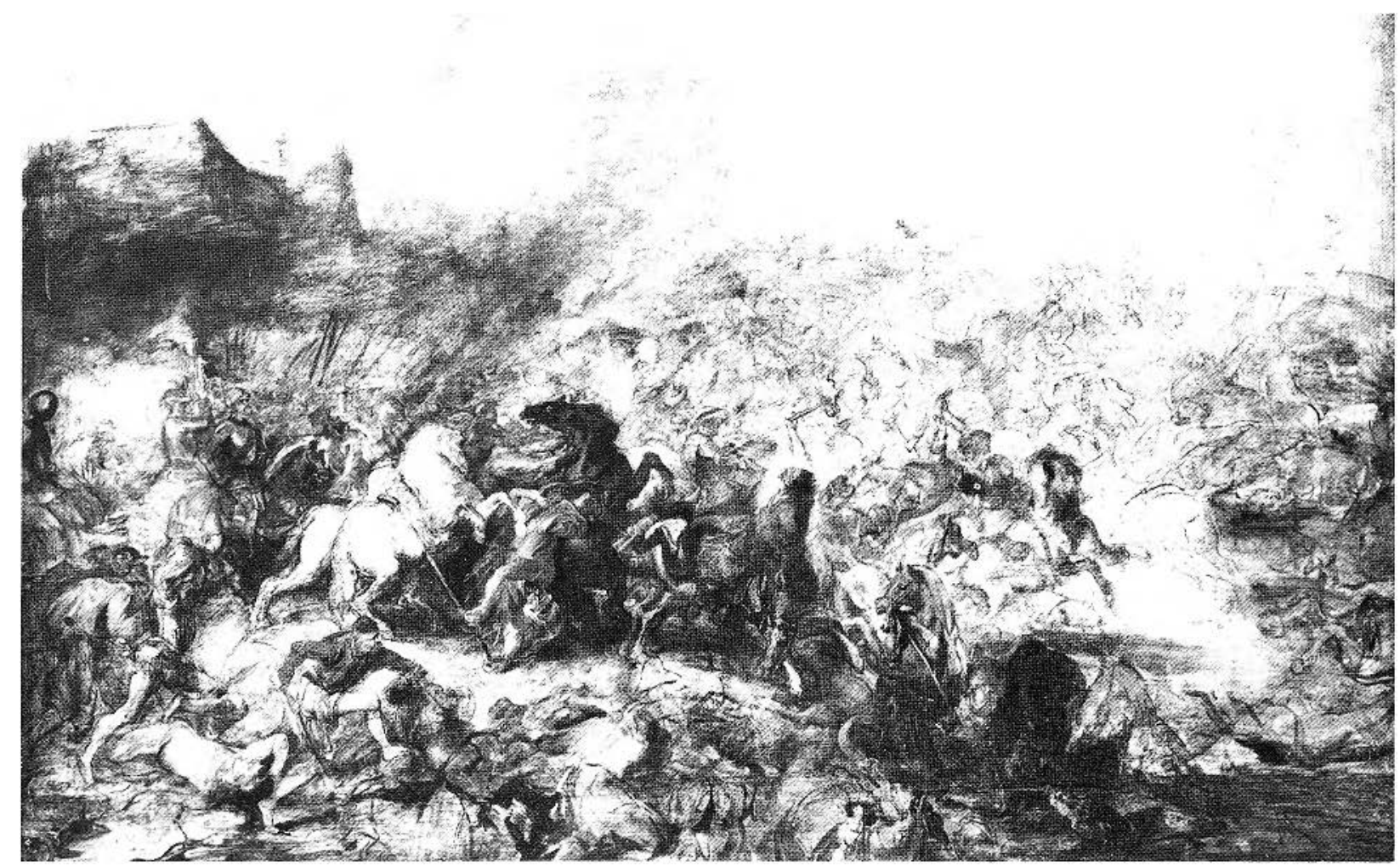

figlre. 6. Peter Paul Rubens. The Battle of Tunis, ca. 1638 . Panel, $76.5 \times 120 \mathrm{~cm}$. Berlin-1)ahlem, Gemäldegalerie Staatliche Museen Preussischer Kulturbesit?. (Photo: Anders).

tion of the batte or the costumes worn by the participants. (harles $v$ appears on horseback just to the lefi of centre. Miiller-Holstede suggests that his figure was inspired by 'litian's renowned Charles " al the Battle of Miahlberg of $1548,{ }^{2 *}$ but in fact it is closer 10 Jan Cornelis\% Vermeven's depiction of the emperor in his Compuest of Tumis series (Fig. 7). ${ }^{20}$

Rubens must have seen Vermeven's Compuest of Tumis in the principal room of the Aleckatr in Madrid. where it hung almost constantly in the serentecmb century." That Rubens did not make use of V'ermeven's generally reliable depictions to lend his Batthe of Tunis a greater historical authenticity is indica-

28 Müller-Hotstede, 81 , als well as Kelch, 74, and Held. ()il Sketches. 1. 386t. leora repreduction and a brilliant cxegesis of Titian's cofucstrian portratit. see l: Panolsks. Problems in Tirian: Mostly Leomographic (New York: New York Lniversily. Press. $19(0)) .81-87$. and fig. 97 .

29 The tapestry of the edifio princeps series in which (Chatless rides in this manner - the eleventh - is lost. For the come-

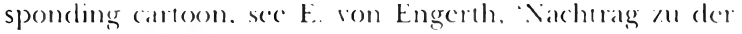
Abhandlung über dic im katiserlichen Besitz bedindlichen Cartone, darstellend Kaiser Karls V' Kriegszug nateh l lunis, von Jan Vermaren, Jahbluch der kunsthistorischen Sammlun-

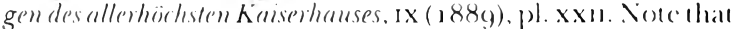
the eighth piece of the series. which is also lost. showed Charles much as in litian's Ballle of Mïhlluege (see von lingerth, pl. $x \mathrm{x} x-\mathrm{xx}$ ). That Rubens knew I itians equestrian portait is certatin. He copied the work in $16003-1604$, during his brief visit to the Spanish court, and later rendered an equestrian portratit of Philip 1 . now lost as a penclant lor tive of the same kind of historical sensibility that is reflected by Frans Francken II's painting as well as by the other early seventeenth-century works under discussion. The Batlle of Tunis is retrospective and nostalgic, evoking the golden age when Charles v ruled over a Catholic empire on which the sun never set. Even in this concept, how'ever, Rubens' painting is essentially unhistorical. The Pax Christiana proclaimed by l'crmcyen's Conquest of Tunis was an aspiration of (harles $\mathrm{r}$ that never came $\mathrm{t}$ ) fruition. Nevertheless, Rubens' work expresses the very essence of the propagandistic message of Vermeren's series. ${ }^{31}$

Titian's painting. Sce M. Jaffé, Rubens and ltaly (O)xlord/ Ithaca: Phaidon Press/Comell University Press, 1(977). (692. pl. 226, and 1.1. I.igo, "Two Seventeenth-Cintury Poems Which link Rubens liquestrian Portrait of Philip) It to

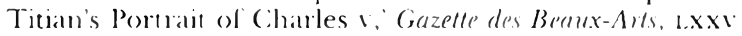
(1970) $34^{(i)}-35^{\circ}$.

30 The evidence is found in S.X. Orso. In the Pressuce of the 'Planel King': Studies in Ant and Deconation al the Coment of Philip) 11 of Spani (Princeron Liniversits Dissertation, 197-8). 1 am not able to specily the relevant pages, as I used the wpescript revised be (Orso for publication by the Princeton Lniversily Press. My own research. again in a Irpescript awating publication, indicates that the editio princeps tapestries of the Timis series remained in the Alcavar, while a second smaller sed made for Mary of Ilungary travedled throughoun Spain and even to Portugal

31 On this subject, sec Ilorn. 233-251. 
FICIRE 7 . Jan Cornelis\% l'enmeren, Charles vas Consader, ca. $154^{60-1551 .}$ Charcoal and water colours on paper. Detail of The March to Rada, artoon for the cleventh apestry of the Conquest of Tunis series. Vicmua, Kunsthistorishes Muscum (Photo: Meyer).

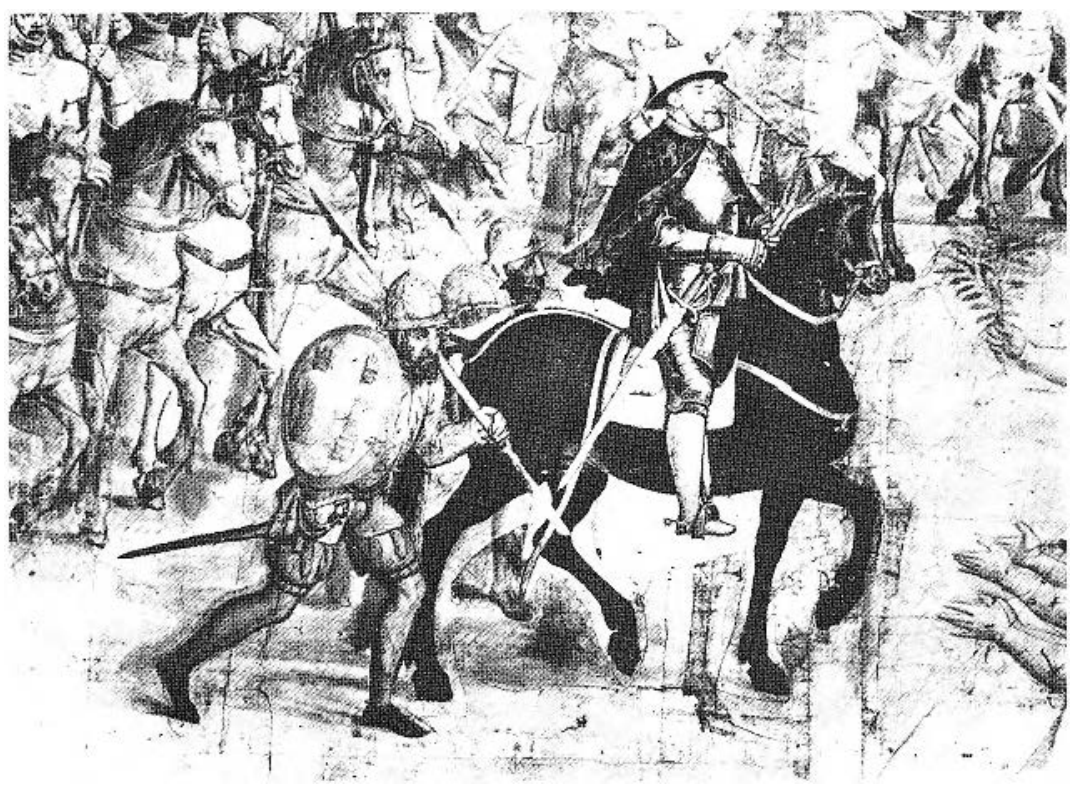

The literature on Rubens' Batle of 'Tunis is curiously devoid of discussions of why and for whom Rubens depicted the crent. Only recently has Julius Ileld pointed out that the successful crusade of his most illustrious Habsburg progentor, Charles r, was of interest to King Philip Iv of Spain." A fairly recent dissertation by Stephen Orso establishes that. throughout the seventecnth century, Spanish monarchs grcatly lavoured Vermeyen's Conquest of Tunis tapestrics for display at a variety of important affairs of state in Madrid and elsewhere. 1 ' his does not prove, however, that Rubens painted his Ballle of Tunis for Philip Iv, whether as an independent work of art or as a modello for a planned larger work. Indeed, Rubens may well have painted the intimate work for himself ${ }^{35}$ However, he saw himself first and foremost as the servant of the Spanish crown and of the regents who represented Philip w in the southern Netherlands. $\Lambda \mathrm{n}$ able diplomat who was skilled in the interpretation of the propaganda of his time, Rubens must have grasped the meaning of Vermeven's Conquest of Tunis and understood why this series and its events loomed so high in the estimation of the Spanish I Iabsburgs. Indeed, their court painter apparently fully shared their nostalgia for the reign of Charles v

There are awo facets of Rubens' conception of the rule of Charles $v$. The first was the notion of the universality of Charles' empire, and the second was the prosperity of the Netherlands within it. These ideas underlay not only his Batle of Tumis but also the decorations conccived by Rubens for the triumphal entry of Archduke ferdinand into Antwerp) in 1635. Predictably the specific concern of the city of Antwerp and of her most distinguished painter expressed in these decorations was that the river Scheldt should be reopened to Flemish shipping." We may reasonably assume that all educated fellow tornsmen of Rubens, including Frans Francken $n$ and his unknown patron, al once understood the intended contrast between the past glory of Charlesi and the present sorry plight of their city.

Wie can now attempt to interpret the meaning of Frans Francken In's Allegony of Charles 1. Francken was in all likelihood asked io paint the work for a reason more important than because sonc unknown patron thought it might be nice to own an allegory on the subject of Charles' abdication. Francken's allegorical painting was very probably commissioned because Charles" abdication. an crent about sevents-five vears in the past, continued to be of topical interest. The erent remained interesting because it contained the prominemt display of the personifications and trappings of a vast enpire that included the still unilied northern and southern Netherlands. It was the dismemberment and decline of this cmpire, which began with (harles' abdicalion and which was hastened along by the revolt of the Netherlands, that was of greal concem to many in the Spanish Netherlands, and especially to the Antwerp of the 1530 and $154 \mathrm{os}$. When we realize this we can understand why Francken's allegory was painted and what it evoked in the breast of the contemporary spectator: the memory of a more harmonious and prosperous age, for Antwerp and for Itanders.

32 Ileld, ()il Sketches, $1.387-388 \mathrm{x}$

33 ()rso. op. (it. (note 30$)$. See mo comments here

34 The latter possibilite is atgued by 1 Hedel. Oil Sketches. 1. 38 7.

35 Held. Oil Sketrhes, 1. 387 , considered this possibility but concluded that the triumph of ('harles' all I unis is a rather improbable subject for such an excrcise.' I disagrec.

36 Martin. passim

37 Natrtin, 10-2.1. As Martm points out. lhe theme of the elosed Schelde had alleads figured in the decorations for the joyous contry of Archduke Eimest of Austria into Antwerp in 1594 
RÉS U MÉ

Dans la partie de droite de L'abdiculion de Charles l' (vers a 6 izo-1640), du peintre anversois Frans Francken ir, unc figure de

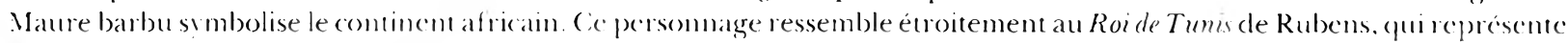
Mulay Ahmad vassal umisien de (harles Y. I alpparit ion presque simultanée de Mulay Ahmad dans ces deux (x:uvres permel

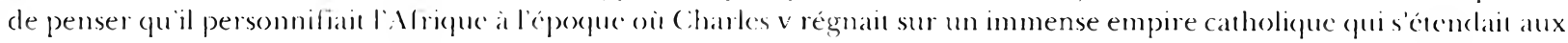

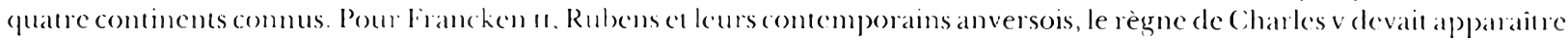
comme une sorte d’àge dor de l'historre des Patys-Bass. La paix et la prospérité de cette période contrastait fortenent arec les guerres sans fin et le déclin économique de leur propré ćpoque. La fermeture du fleure Escault à toute navigation (exceprion faite pour les bateaux hollandais) constituait unc source majeure de mécontentement. Des (xurres comme La conquête de

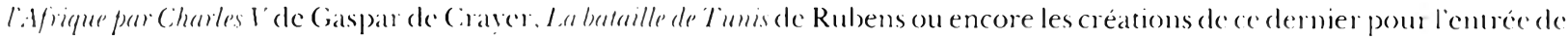

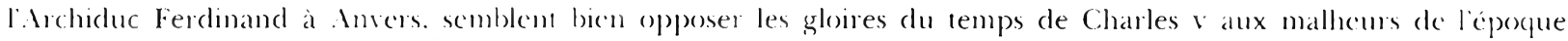

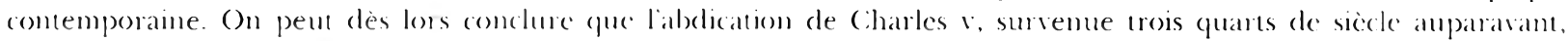

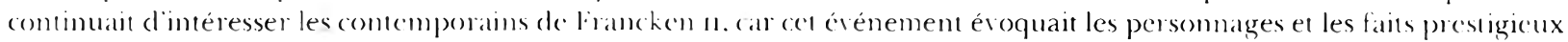

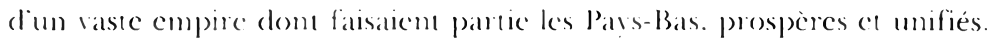

